\title{
Metáforas de um drama histórico O Judeu, de Bernardo Santareno
}

\author{
Cristina Abranches Guerreiro
}

Entre as vozes que, no panorama do teatro português do século $X X$, contrariaram o silêncio imposto pela censura, Bernardo Santareno será decerto um dos nomes cimeiros. Perseguido e forçado ao exillio pelas suas conviç̧ões políticas, considerava O Judeu a sua obra dilecta: a vida do célebre dramaturgo setecentista condenado pela Inquisição (que a Camilo inspirara um romance histórico) serviu de pretexto para uma reflexão sobre a intolerância e ausência de liberdade que também caracterizavam o seu próprio tempo.

Nascido em 1705, no Rio de Janeiro (onde os avós paternos, abastados cristãos-novos, se tinham instalado no segundo quartel do século XVII), António José da Silva veio, com a família, para Lisboa em Outubro de 1712, quando sua mãe, Lourença Coutinho, acusada de judaísmo, foi enviada para a capital do reino, para ai ser julgada pelo Santo Ofício.

Em Agosto de 1726, estudante de leis em Coimbra, António foi, pela primeira vez, preso e torturado pela Inquisição. Ajudado por amigos influentes, é libertado a 13 de Outubro e forçado a abjurar o judaismo. Terminados os estudos, em 1728, volta a Lisboa, para exercer advocacia

Cristina Abranches Guerreiro é doutorada em Literatura Grega pela Universidade de Lisboa (com a tese $O s$ sonhos régios da Pérsia

nas Histórias de Heródoto, 1999) e é Professora Auxiliar do

Departamento de Estudos Clássicos. com seu pai. Desenvolve paralelamente (entre 1733 e 1738) uma carreira literária, reagindo com a força da escrita contra o despotismo que o persegue numa sociedade que considera injusta. Criador de óperas para as marionetas do Teatro do Bairro Alto, torna-se um dos maiores autores dramáticos portugueses (e, depois de Gil Vicente, um dos mais representados), pela riqueza e vivacidade dos seus diálogos, pelo cómico de personagens e situações e pela força crítica da sua verve satírica.

A 5 de Outubro de 1737, por denúncia de Leonor Gomes (uma escrava negra a quem recusara carta de alforria), é de novo preso, com a mãe e a esposa (sua prima Leonor Maria de Carvalho). Durante um ano, enclausurado no Paço dos Estaus, é acusado de práticas judaizantes, torturado e, finalmente, condenado à pena capital.
A sua sentença foi lida a 16 de Agosto, poucos dias antes de ser queimado nas piras da Inquisição, como "judeu, relapso e negativo", mas também por causa da sua prosperidade económica (Santareno 1978: 135), e da crítica política e religiosa da sua obra (Ibidem: 225), que as multidões aplaudiam reconhecendo as alusões veladas a personagens do seu tempo, que suscitavam o riso. No auto de fé do Campo da Lã, a 18 de Outubro de 1738, a confissão das suas culpas valeu-lhe ser estrangulado antes de se tornar pasto das chamas. Sua mãe morreria pouco depois; levando consigo a filha, a viúva do dramaturgo procurou refúgio na Holanda, onde os judeus não eram vitimas de perseguição.

$\mathrm{Na}$ imagem do iníquo tratamento infligido pela Inquisição ao poeta setecentista, Bernardo Santareno transpõe, quase sem metáfora, a situação que a ditadura impunha aos homens de letras do século XX. Editada pela primeira vez em 1966, a narrativa dramática O Judeu ecoava um hino à liberdade, impossivel de encenar numa das mais severas fases da repressão: recorde-se que, no ano anterior, fora extinta a Sociedade de Escritores (a cuja direcção Santareno pertencia) e tinham sido suspensas as representações de 0 motim, de Miguel Franco; proibida fora também a circulação das peças $A$ estátua e $A$ guerra santa, de Luis de Sttau Monteiro, a quem a censura prendera, além de encerrar a editora que as dera a lume.

Durante todo o ano de 1980, ansioso por ver representada a sua obra-prima (cuja versão integral, em três actos, preencheria cerca de cinco horas de espectáculo), Bernardo Santareno trabalhou com o encenador Rogério Paulo numa redução do texto a dois actos, numa adaptação cénica que findaria após a morte do dramaturgo, com a colaboração de Luiz Francisco Rebello.

Três meses e meio de ensaios conduziram a uma espectacular produção com setenta figuras em palco (entre as quais trinta e um actores, muitos dos quais escolhidos pelo autor), uma cuidada caracterização de época (com cerca de três centenas de magníficos figurinos, concebidos 

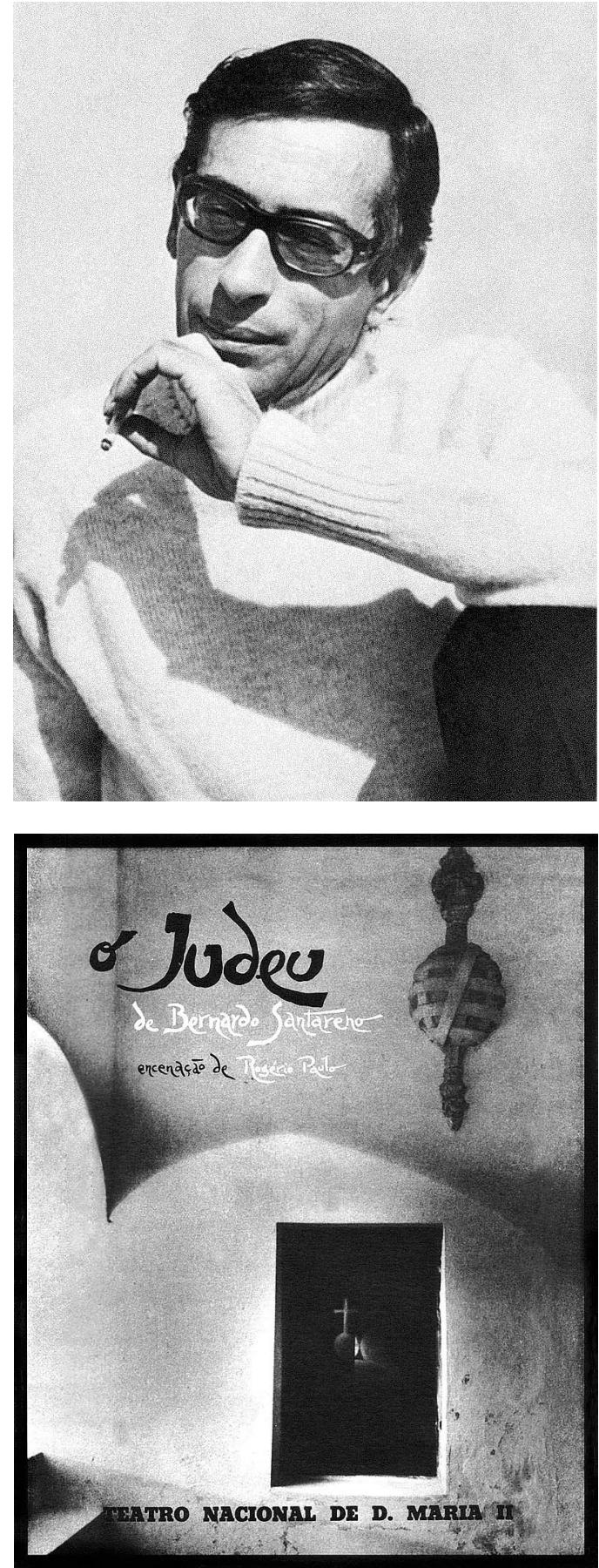

por António Alfredo), fruto de um minucioso trabalho de pesquisa, que incluiu a recuperação do Hino da Inquisição, cantado em Latim pelo coro da Universidade de Lisboa dirigido por Francisco d'Orey.

A 20 de Fevereiro de 1981, O Judeusubia, pela primeira vez, à cena, no Teatro Nacional D. Maria II. No início de cada representação, para situar a assistência no tempo e no espaço da acção, descia sobre o palco uma enorme tela com uma gravura da época, sobre a qual se liam as seguintes palavras: "Palácio dos Estaus - Sede da Inquisição em Lisboa. Sobre as suas ruínas foi construído o Teatro Nacional D. Maria II". Por ironia do destino, a ficção recriava a realidade, no mesmo local em que fora encarcerado e condenado à morte o protagonista do enredo. Presença constante, e espécie de alter ego do autor entre as personagens do drama, é Francisco Xavier de Oliveira (no texto designado por Cavaleiro de Oliveira), um intelectual no exilio (em vão perseguido e queimado em efígie pela Inquisição), que desempenha as funções de "narradorcomentador" (Ibidem: 38).

A propósito da Vida do grande D. Quixote de la Mancha e do gordo Sancho Pança (a primeira obra dramática do Judeu, levada à cena em 1733), o "narrador-comentador" sublinha a crítica literária aos poetas sem inspiração nem talento, "ocos e empoados", "panegiricadores de El-Rei", que os enche de favores (Ibidem: 143): após a vitória de D. Quixote sobre tais inimigos da literatura, o inculto Sancho decide escrever um poema sobre a batalha - "um zurro" semelhante às criações desses escritores sem arte (Ibidem: 145).

No segundo acto, um outro excerto da mesma ópera de António José da Silva (Ibidem: 146-153; cf. 92) ilustra a imagem da tirania na época do poeta, com as suas vitimas inocentes, as testemunhas falsas, a tortura física e psicológica. Senhor da llha dos Lagartos, onde a justiça é vesga, Sancho Pança não ouve as queixas dos que vêm pedir-Ihe justiça, e a violência de que é capaz inspira-Ihe a pena capital. Segundo o "narrador-comentador", Portugal é semelhante à llha dos Lagartos (Ibidem: 154). Ergue-se a voz do Judeu, para chamar ao rei grande governador da Ilha dos Lagartos. 0 seu público reconheceria em tal cena uma metáfora do injusto poder da Inquisição; o

leitor/espectador da peça de Bernardo Santareno associarIhe-á inevitavelmente a imagem das vítimas da Polícia de Intervenção e Defesa do Estado Novo.

No início do terceiro acto, perturbantes imagens oníricas agitam o sono da mãe do Judeu. Entre as anotações cénicas, Bernardo Santareno menciona alguns recursos para sublinhar o pesadelo da personagem:

Num écran que surge ao fundo, serão projectados fragmentos de filmes-documentários dos campos de exterminação nazis para judeus, durante a última guerra. As imagens escolhidas,
Bernardo Santareno, 1920-1980.

Capa do programa de O Judeu,

de Bernardo Santareno, enc. Rogério Paulo, Teatro Nacional D. Maria II, 1981 
que serão autênticas, mostram os massacres de judeus nas câmaras de gás: massas imensas de vitimas, esfarrapadas ou nuas, movendo-se como num pesadelo, sem elementos precisos no vestuário, ou outros, capazes de as temporalizar numa época determinada. Pormenores de horror: o medo angélico das crianças, o rosto da morte nos seres jovens e belos, o misticismo messiânico dos velhos. 0 som e a luz criarão a necessária unidade entre as imagens filmicas e as personagens vivas do palco: as cenas projectadas devem sair de dentro de Lourença, da raiz da sua angústia como ondas de pavor. Ouvir-se-á, durante a projecção, o velho canto de amor judaico: Shema Yisrael Adonoi Elohenu Adonoi Echod... Ao ritmo feroz dos tambores de guerra, uma Voz Trágica irá rememorando os nomes malditos dos campos de extermínio. (Ibidem: 158)

Ao comentar a vida do Judeu, o narrador tece comentários que não se confinam ao Portugal do século XVIII: "Portugal pode comparar-se a um relógio atrasado pela malícia e perversidade daqueles que têm a cargo darIhe corda" (Ibidem: 38). Reconhece-se a ironia trágica da sua esperança, ao imaginar a ventura dos cidadãos do século XX: "Ai, como vos amo, admiro e invejo, a vós, para quem estes crimes nefandos do Poder mais não serão que as sombras dum pesadelo, vindas da noite álgida do passado, e logo desfeitas pelo Sol claríssimo dos luminosos dias que então vivereis" (Ibidem: 46). Confiante no futuro, imagina o julgamento que sobre as atrocidades do Santo Oficio formularão "aqueles felizes mortais que terão a dita imerecida de viver no Portugal do século XX" (Ibidem: 90) "E vós outros, Portugueses ilustrados e livres, que todos o sereis nesse formoso século XX..., haveis de nos pensar e lamentar" (Ibidem: 202).

Santareno aproxima o passado e o presente, jogando com a ambiguidade de muitas falas do Cavaleiro de Oliveira. A pergunta retórica "Com que cara pode El-Rei exigir do povo que dê a vida, nas guerras, para defender e garantir Portugal? (...) Para defender aqueles mesmos ideais que Ihes mantêm as cadeias nos pés e nas mãos?!" (Ibidem: 72 73) é também uma alusão à guerra colonial. A imagem da ditadura do Estado Novo perpassa claramente no desabafo: "Na Europa civilizada, Portugal é a fortaleza do Medo; espiões e policias os seus alicerces e guarda!" (Ibidem: 94)

Tão válida no século XVIII como no século XX é a última exortação do "narrador-comentador": "Iluminai o povo de Portugal" (Ibidem: 237). Neste derradeiro apelo, ecoa a esperança (intemporal) da justiça: "Lutai, combatei com quanto alento tiverdes, para que os atrozes acontecimentos que aqui me ouvistes contar não mais voltem a acontecer neste provado Reino!" (Ibidem: 255).

\section{Referência bibliográfica}

SANTARENO, Bernardo (1978), O Judeu, Lisboa, Ática. 